\title{
Environmental Exposure to Glyphosate and Reproductive Health Impacts in Agricultural Population of Argentina
}

\author{
Medardo Avila-Vazquez', Flavia S. Difilippo', Bryan Mac Lean', Eduardo Maturano², \\ Agustina Etchegoyen ${ }^{3}$ \\ ${ }^{1}$ Chair of Pediatric Clinic, Faculty of Medical Sciences, National University of Cordoba, Cordoba, Argentina \\ ${ }^{2}$ Epidemiology Committee of Virology Institute Jose Maria Vanella, Faculty of Medical Sciences, National University of Cordoba, \\ Cordoba, Argentina \\ ${ }^{3}$ Center for Environmental Research, Faculty of Exact Sciences, National University of La Plata, La Plata, Argentina \\ Email: medardoavilavazquez@gmail.com
}

How to cite this paper: Avila-Vazquez, M., Difilippo, F.S., Lean, B.M., Maturano, E. and Etchegoyen, A. (2018) Environmental Exposure to Glyphosate and Reproductive Health Impacts in Agricultural Population of Argentina. Journal of Environmental Protection, 9, 241-253.

https://doi.org/10.4236/jep.2018.93016

Received: January 18, 2018

Accepted: March 23, 2018

Published: March 26, 2018

Copyright $\odot 2018$ by authors and Scientific Research Publishing Inc. This work is licensed under the Creative Commons Attribution International License (CC BY 4.0).

http://creativecommons.org/licenses/by/4.0/

\begin{abstract}
Argentina annually utilizes 240,000 tones of glyphosate in industrial agriculture and a change in the profile of morbidity is perceived for physicians of agricultural areas; now reproductive disorders seem to prevail. The objective of this study is to determine concurrence of glyphosate exposure and reproductive disorders in a typical argentine agricultural town (Monte Maíz). An ecological study was developed with an environmental analysis of pollution sources including measurements of glyphosate and other pesticides and a cross-sectional study of spontaneous abortions and congenital abnormalities prevalence. Glyphosate was detected in soil and grain dust and was found to be at an even higher concentration in the village soil than in the rural area; 650 tonnes of glyphosate are used annually in the region and manipulated inner town contaminating the soil and dust in suspension of the town creating an burden of environmental exposure to glyphosate of $79 \mathrm{~kg}$ per person per year. We do not find other relevant sources of pollution. The spontaneous abortion and congenital abnormalities rates are three and two times higher than the national average reported by the national health (10\% vs. $3 \%$ and $3 \%$ - $4.3 \%$ vs $1.4 \%$ respectively). Our study verified high environmental exposure to glyphosate in association with increased frequencies of reproductive disorders (spontaneous abortion and congenital abnormalities) in argentine agricultural village, but is unable to make assertions cause-effect. Further studies are required with designs for such purposes.
\end{abstract}




\section{Keywords}

Glyphosate, Spontaneous Abortions, Congenital Abnormalities, Environmental Exposure, Environmental Health

\section{Introduction}

In 1996, Argentina began to grow genetically modified (GM) seeds, and used currently 25 million hectares where 12 million people live; these crops have generated a substantial increase in the pesticide consumption. In 2013, Argentina sprayed 240,000 tons of Glyphosate [1] [2]. A change in the profile of morbidity and mortality is perceived for physicians of agricultural areas; now reproductive disorders and cancer seem to prevail [3] and recently the International Federation of Gynecology and Obstetrics expressed concern about reproductive health impacts of exposure to toxic environmental chemical [4]. Monte Maíz town (Union District in Province of Cordoba) lies at the heart of Argentina's agricultural area, the region of greater agricultural productivity in the country, where soy, maize, and wheat are grown in the centre of the country. In recent years, local governmental authorities along with local residents and doctors were worried about an increase apparent in the number of spontaneous abortions, congenital abnormalities and cancer, thus requesting an assessment of health status to the Faculty of Medical Sciences, National University of Cordoba (UNC). The community had conducted a health census in 2007 (unpublished), carried out by teachers and other volunteers, in which high rates of spontaneous abortions and cancer were identified. There are few epidemiological studies on the environmental health of rural populations in Argentina and very little has been published to date. The objective of this study is the Monte Maíz environmental contamination recorded, mainly the presence of glyphosate and other pesticides and checking whether spontaneous abortions prevalence and congenital abnormalities prevalence were increased. It was our goal to verify concurrence of glyphosate environmental exposure and those reproductive disorders; cancer rates were also measured and this outcome has already been recently published by the authors [5].

\section{Material and Methods}

An exploratory ecological study on reproductive disorders and environmental pollution was performed, consisting on the one hand of an epidemiological study (a cross-sectional study) with a household survey of health addressed to the entire population (population survey), designed to geo-reference each record in the village with use of nine ratios census (R) by National Institute Census that divide the town into nine sectors outweighed demographically as seen in the map of Figure 1. Through the household survey, we checked spontaneous abortions prevalence (women aged between 15 and 45 years old who have suffered 


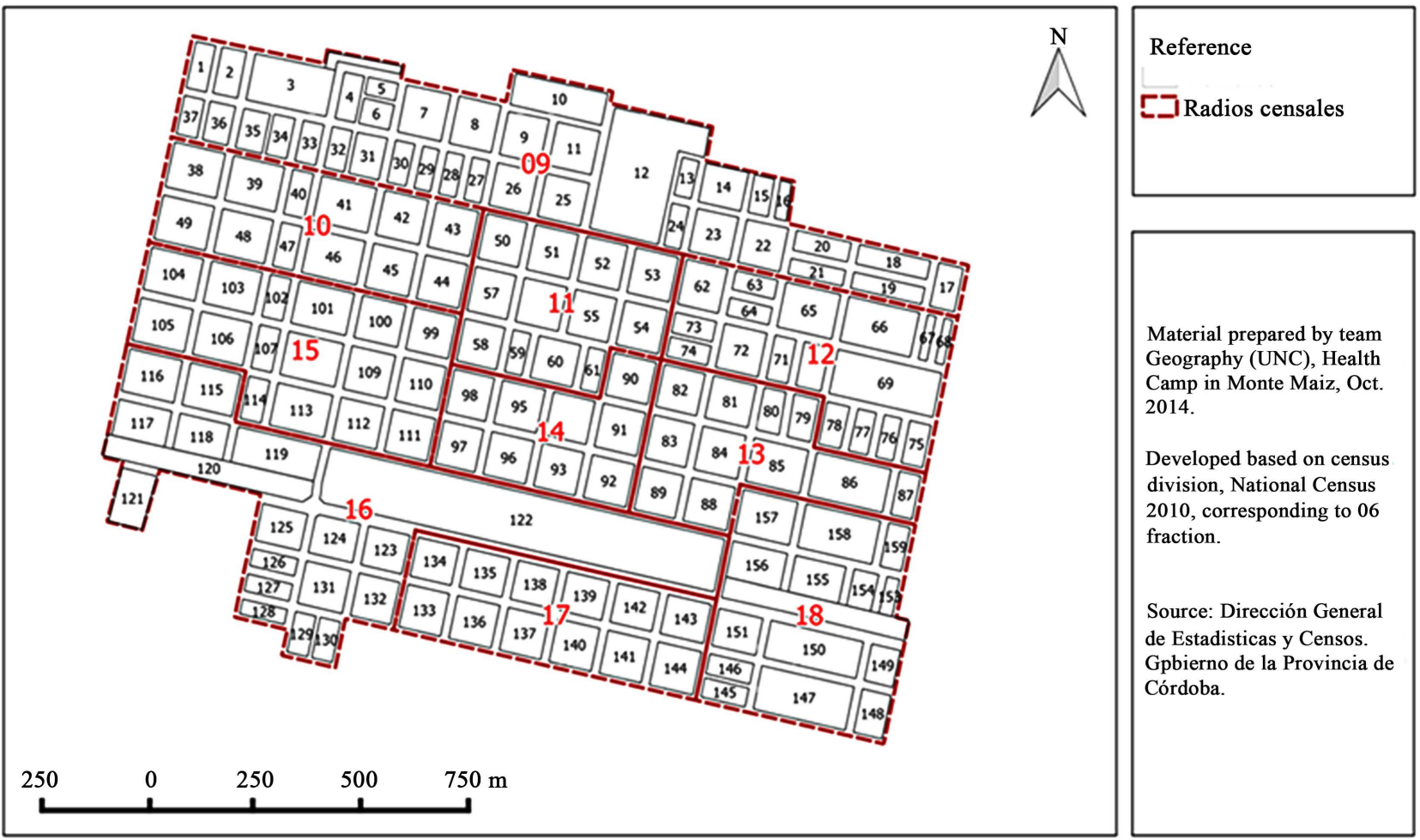

Figure 1. Map Ratius Census of Monte Maíz by National Institute Census divide the town in nine sectors outweighed demographically.

spontaneous or unexplained abortion on the last 5 years and with 5 or more years of living in Monte Maíz) and congenital abnormalities prevalence (children with major congenital abnormalities alive at the time of the interview), these were dependent variables, while sex, age, occupation, stay in the village, smoke, ratio census residence, educational level and the presence of environmental contaminants were the independent variables. On the other hand, an environmental analysis recording sources of contamination such as landfills, cell site (cell tower), electric power transformers, industrial sites, stockpiles of grains, storehouses of pesticides, and spraying machines. We interviewed community and government stakeholders, business owners, city officials, teachers, farmers and workers that sprayed pesticides, in order to recognize the performance of industries, local public services, and agribusiness (drinking water, sewer management, household waste, industries pollutions, routines and doses of pesticides use). Samples of environmental matrices (water, soil, grain husks) were collected and analyzed by the Center for Environmental Research, Faculty of Exact Sciences of National University of La Plata, which selected twelve internal and peripheral sites in the town to examine the presence of glyphosate, its metabolite aminomethylphosphonic acid (AMPA), and currently used pesticides (chlorpyrifos, endosulfan, cipermetrina, atrazine, $2.4 \mathrm{D}$, and epoxiconazole). Both pretreatment and analysis of pesticides were performed under international regulations using liquid chromatography-mass spectrometry [6] [7]. A dosage of arsenic (As) was conducted in domestic water network using hydride generation atomic absorp- 
tion spectrometry.

The study area was Monte Maíz, a town located on Provincial Route $\mathrm{N}^{\circ} 11^{\prime}$, $33^{\circ} 12^{\prime}$ South latitude and $62^{\circ} 36^{\prime}$ West longitude of Greenwich, at a height above sea level of 114 metres; the town is 113 years old and has 7788 inhabitants (8045 including residents of surrounding rural areas). Agriculture is the main economic activity with complementary metalworking industry that is located on the Southern edge of the town [8].

\subsection{Statistical Analysis}

Crude rates were obtained through a database and numerical matrix, a bivariate correlation Pearson analysis was conducted to assess the association of spontaneous abortions and congenital abnormalities with independent variables, included the spatial distribution according to ratios census in which the town was divided (R09-R18). We built maps for spontaneous abortions and congenital abnormalities and pollution sources using Quantum GIS 2.4 software and created contingency tables to perform relational measurements between exposure and disease. For this end, the following software was used: INFOSTAT (UNC), SPSS, and EPIDAT (PAHO). Rates of spontaneous abortions and congenital abnormalities of Monte Maíz were compared with the national rates reported by the National Registry of Congenital Abnormalities (RENAC) of the National Health Ministry [9].

\subsection{Study Conduct}

Physicians or medical students carried out the fieldwork during October 2014; all health surveys were conducted by final year medicine students of UNC and medical professors. The study was conducted in accordance with the Declaration of Helsinki and under the framework of Act 9694 Article 2 of the Province of Cordoba in accordance with the law regulating health research and was approved by the Bioethics Committee established by this law for observational studies [10]. All surveys were performed after obtaining informed consent.

\section{Results}

\subsection{Environmental Analysis}

In Monte Maíz the electrical network is powered by medium-voltage power distributed in the urban area, with substations of $33 \mathrm{kV}$ to $380 \mathrm{w}$, no high voltage. Has a sewer system with a domestic collection network reaching every home; solid urban waste is collected by a municipal service that has a Solid Waste plant. Their hinterland has soybeans on 45,000 ha and maize on 20,000 ha which are main summer crops and wheat on 15,000 ha as a winter crop. We identified an open landfill, 800 meters northeast of the town's limit, with no evidence of fire in the last 5 years. There is an absence of forestry across the periphery of the town, which is replaced by soybean and maize crops, starting at the immediate edge of houses. These crops are frequently treated, with pesticide, by ground 
equipment and crop dusters. At the southwest of Monte Maíz, we found two livestock breeding farms, and, on the west side, a flood zone, with ponds, a park, and a sewage treatment plant between the crop fields.

There are two farm equipment industries, located at the southern tip of the town; these factories use methane gas as a source of energy. The sources of electromagnetic radiation were two cellphone towers, located in R9 and R12 which are highlighted on the map of pollution factors on Monte Maíz in Figure 2 (there are two other towers located outside of the urban area). The population of Monte Maíz receives drinking water of very good quality, drinkable and arsenic-free. Within the inhabited village, there are silos of cereal from where soy and corn husks are released (grain dust) shown on the map in Figure 2 and were identified twenty-two deposits for spraying machines and pesticide containers used in the region.

Local agronomists and agrochemical applicators report that in Monte Maíz GM soybean and corn crops use 10 kilograms of glyphosate per ha per year. Six hundred and fifty tonnes of glyphosate are aerosolized in the area, creating a general burden of environmental exposure to glyphosate of $79 \mathrm{~kg}$ per person per year, which varies for agricultural or non-agricultural activity and for spatial distribution of glyphosate. This region utilizes nine hundred seventy five tonnes of all pesticides each year.

\begin{tabular}{|c|}
\hline Map 2: Monte Maiz \\
Environmental Factors Pollution
\end{tabular}
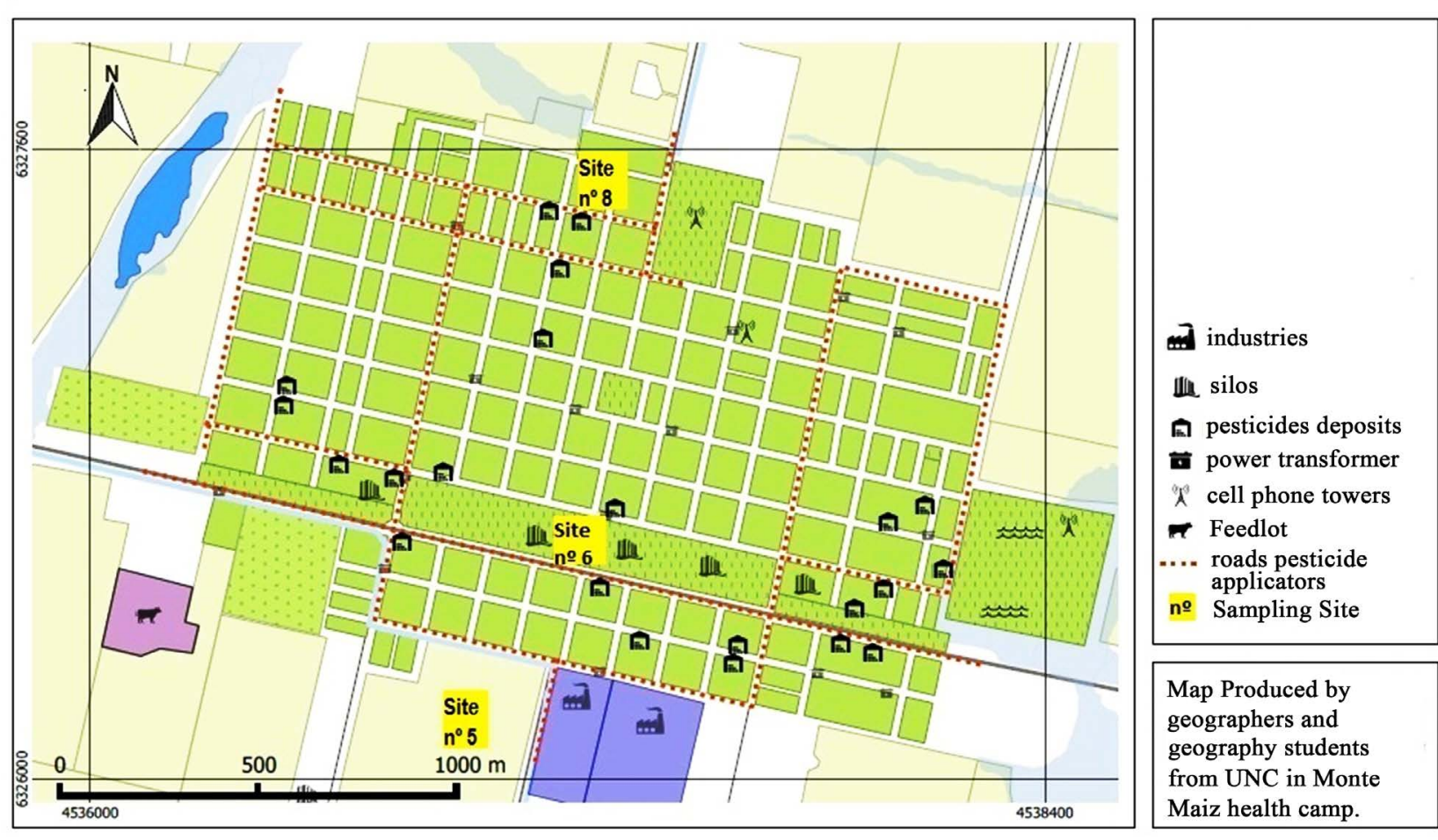

Figure 2. Map of environmental factors pollution on Monte Maíz and main sampling site. 


\subsection{Chemical Contaminants Test}

Herbicide glyphosate and AMPA was detected in 100\% samples of soil and husk. In grain husks from silos, glyphosate and AMPA prevailed (505 and $607 \mathrm{ppb}$ ), followed by chlorpyrifos (14 ppb) and epoxiconazole ( $2.3 \mathrm{ppb}$ ) as shown in Table 1. Sampling site $\mathrm{N}^{\circ} 6$ (map in Figure 2), belonging to a children's playground, contained 68 times more glyphosate than site $\mathrm{N}^{\circ} 5$, belonging to a farm field of resistant to glyphosate corn. Similarly, site $\mathrm{N}^{\circ} 8$, where the soil sample was taken from the sidewalk next to pesticides deposits, had the highest concentration of glyphosate (3868 ppb), AMPA (3192 ppb), and all pesticides.

Glyphosate also had the highest concentrations among all the matrices studied (3868 ppb), exceeding by far the other pesticides: endosulfan II (337.7 ppb) and chlorpyrifos (242 ppb) (see Table 1). There were minimal concentrations of pesticides in drinking water; also, the arsenic in drinking water was less than $5 \mathrm{ppb}$.

\subsection{Epidemiological Analysis}

Overall, $92 \%$ households were visited, $4.8 \%$ corresponds to households that refused to answer the survey. Some houses were uninhabited at the time of the visit. The information was collected from 4859 people (62\% of the population), its characteristics are available in Table 2.

98 spontaneous abortions occurred in the last 5 years among 981 surveyed women of reproductive age; 62 of them had only one event, 15 had two, and 2 of them had three abortions, a unintended abortions prevalence rate of $10 \%$ per 100 women of reproductive age; 79 women among 981 were those who suffered spontaneous abortions (8\%).

Among the population studied there were 853 births in the last 10 years, 25 children presented major congenital abnormalities and were alive at the time of the study (four abnormalities of nervous system, five genitals, four limbs, three renal and urinary, two digestive, four cardiopathies and one biliary atresia, cleft lip and thyroglossal cyst), a prevalence rate of 3\% (Table 3), not including

Table 1. Measurements pesticides in environmental matrices, main findings. References located sampling site (S5, S6 and S8) in map of Table 1. DNC: Detectable no quantifiable. Center for Environmental Research, Faculty of Exact Sciences of National University of La Plata.

\begin{tabular}{cccccccccc}
\hline S: Site sampling & Glifosato & AMPA & $2.4 \mathrm{D}$ & Atrazina & Clorpirifos & Endosulfan I & Endosulfan II & Cipermetrina & Epoxiconazol \\
\hline $\begin{array}{c}\text { S1 drinking water } \\
\text { network }\end{array}$ & $<2 \mathrm{ppb}$ & $<2 \mathrm{ppb}$ & $<1 \mathrm{ppb}$ & $<0.5 \mathrm{ppb}$ & $\mathrm{DNC}$ & $\mathrm{DNC}$ & $\mathrm{DNC}$ & $<0.005 \mathrm{ppb}$ & $<0.005 \mathrm{ppb}$ \\
$\begin{array}{c}\text { S5 crop field } \\
\text { soil }\end{array}$ & $41 \mathrm{ppb}$ & $116 \mathrm{ppb}$ & $<5 \mathrm{ppb}$ & $6.4 \mathrm{ppb}$ & $242 \mathrm{ppb}$ & $<1.5 \mathrm{ppb}$ & $2.2 \mathrm{ppb}$ & $58 \mathrm{ppb}$ & $3 \mathrm{ppb}$ \\
$\begin{array}{c}\text { S6 children's } \\
\text { playground soil }\end{array}$ & $2792 \mathrm{ppb}$ & $797 \mathrm{ppb}$ & $\mathrm{S} / \mathrm{D}$ & $\mathrm{S} / \mathrm{D}$ & $4.4 \mathrm{ppb}$ & $<1.5 \mathrm{ppb}$ & $<1.5 \mathrm{ppb}$ & $4 \mathrm{ppb}$ & $3.4 \mathrm{ppb}$ \\
$\begin{array}{c}\text { S6 children's } \\
\text { playground grain } \\
\text { husks from silos } \\
\text { S8 pesticides }\end{array}$ & $505 \mathrm{ppb}$ & $607 \mathrm{ppb}$ & $\mathrm{S} / \mathrm{D}$ & $\mathrm{S} / \mathrm{D}$ & $14 \mathrm{ppb}$ & $\mathrm{DNC}$ & $<1.5 \mathrm{ppb}$ & $\mathrm{DNC}$ & $2.3 \mathrm{ppb}$ \\
deposits soil & $3868 \mathrm{ppb}$ & $3192 \mathrm{ppb}$ & $128 \mathrm{ppb}$ & $52.5 \mathrm{ppb}$ & $150.4 \mathrm{ppb}$ & $17.5 \mathrm{ppb}$ & $338 \mathrm{ppb}$ & $180 \mathrm{ppb}$ & $6.3 \mathrm{ppb}$ \\
\hline
\end{tabular}


Table 2. Monte Maíz Population surveyed: characteristics, absolute numbers and percentages.

\begin{tabular}{cc}
\hline Characteristics & Magnitude \\
Male & $4959(61.98 \%)$ \\
Female & $2361(47.61 \%)$ \\
Average age of Population & $2597(52.37 \%)$ \\
People 0 - 15 years & 36.03 years \\
People $\geq 16$ years with complete primary education & $1175(23.69 \%)$ \\
People with health insurance & $3313 / 3744(88.49 \%)$ \\
Percentage of people with $\geq 5$ years residence time & $3859(78.01 \%)$ \\
Families of rural workers, farmers and agronomists & $4141 / 4328(95.68 \%)$ \\
Smokers & 270 families, 970 persons \\
\hline
\end{tabular}

Table 3. Results of epidemiological assessment: disease, number of cases and rate.

\begin{tabular}{ccc}
\hline Reproductive Impacts & Number of cases & Rate \\
\hline Spontaneous abortions & $98 / 981$ & $10 \%$ \\
Women with spontaneous abortions & $79 / 981$ & $8 \%$ \\
Congenital abnormalities alive & $25 / 853$ & $3 \%$ \\
Congenital abnormalities total estimate & $40 / 853$ & $4,7 \%$ \\
\hline
\end{tabular}

malformed children who died during this period. Including the dead (calculated in twelve cases) the rate of congenital anomalies would reach $4.3 \%$ because the WHO estimates a congenital anomalies mortality of $40 \%$ in ten years [11].

Spontaneous abortions shown correlate with young women and women living in R16 and R17 with a significance of $0.05 \%$, these radiuses (R) are the ones blown by the wind coming from where are the cereal stores. Congenital abnormalities showed no significant correlation with independent variables.

Association levels were measured as occurrence rate (ORs) arising from contingency tables $(2 \times 2)$; the OR for spontaneous abortions in women from Radius 16 and Radius 17 with respect to other Radius was 1.29 (CI 0.71 - 2.34) with a non significant $\mathrm{p}$-value, so that despite the existence of apparent risk of abortion in those areas, the presence of bias could not be excluded.

\section{Comments}

Seeds that are genetically manipulated to contain a transgene have the ability to survive in saturated environments with glyphosate, an herbicide used to eradicate other plants. Glyphosate interferes with the vital metabolism of plants, but not with transgenic plants for which an alternative metabolic pathway was generated through bioengineering. Since 1996, when GM soy was introduced in Argentina, its use has continued to expand due to the high profit generated by its 
commercialization and easy harvest [12] as the extension of this crop increases, so does the use of glyphosate. Currently, Argentina is using 240,000 tons of glyphosate per year. This has increased year-on-year as a consequence of herbicide-resistant weeds requiring higher doses of glyphosate and the combined use of other herbicides as $2.4 \mathrm{D}$, atrazine, etc. [13]. This increase has resulted in $5 \mathrm{~kg}$ of glyphosate per person per year as potential exposure burden for all inhabitants of the country, greater in agricultural areas.

Monte Maíz shows the effects of this agricultural model, as is a production boom in the region, a high standard of living among its population, and the relocation of local farmers in the village; these farmers left rural areas and moved with their families work equipment and supplies. Deposits of agricultural equipment are multiplying inside the village (twenty-two in total), the largest deposits in town are in R15 and are five pesticide storage sites. A total of 650 tons of glyphosate per year is concentrated, manipulated and has surrounded the town, which now faces fields that are sprayed daily. Glyphosate was found in $100 \%$ of soil and husk dust samples, the concentration was 10 times higher than that of other pesticides, this demonstrates that, of all pesticides that pollute the environment, glyphosate is the most prevalent. Concentrations found in inner town are several times higher than in the soil in cultivated fields (see Table 1), reaffirming the impression that the town is at the operational center of the sprayed area. Glyphosate is also high in grain dust, it is also accompanied by other pesticides their joint presence discards that glyphosate is high within the village due to its use in gardening.

In metalwork factories, no significant pollution was found; the density per $\mathrm{km}^{2}$ of the source of electromagnetic radiation such as cell site, high voltage power lines, and electrical voltage transformers is low compared with source electromagnetic radiation density in big cities, which minimizes the value of this pollution; for example Nueva Cordoba, a neighborhood of Cordoba city, which is located on the same surface as Monte Maíz with a larger population, has nine cell sites, while there are only two towers in Monte Maíz [14], although, a weakness of the study is the lack of electromagnetic radiation direct measurements.

Moreover, household garbage management, sewage, and contaminant-free water (for 16 years now) remove these contaminating factors from the observed pathologies. Thus, pollution with glyphosate and to a lesser extent with other pesticides is the predominant factor in the environmental contamination analysis of Monte Maíz.

The rate of spontaneous abortions in five years (10\%) in Monte Maíz was three times higher than that reported in a national analysis conducted in 2005 for the National Health Ministry (0.6\% per year) [15], and also higher than that of a social-health survey recently conducted (2016) by our team in a neighbourhood of Cordoba where the prevalence of spontaneous abortions was $3.7 \%$ in 5 years [16]. The spatial distribution of abortions shows a backlog of cases in the sector (R16 and R17) that is most contaminated with glyphosate-impregnated 
grain husk, although the association is not significant. This increased prevalence is consistent with the findings of Aiassa et al. that detected a spontaneous abortions rate of $19 \%$ between 166 households in the farming village of Las Vertientes (Cordoba, $180 \mathrm{~km}$ from Monte Maiz) [17]. The "Ontario Farm Family Health Study" refers $18.7 \%$ of spontaneous abortions rate in farm families with a significant risk for preconception exposure to glyphosate [18]. In our population young mothers were linked to this perinatal outcome and not the other way round; smoking was not linked to abortion either. The population is not inbred (it is a large town made up of farmers and steelworkers) and its social structure shows an excellent socioeconomic status measured in rate of unmet basic needs. Neither maternal age, toxic habits or poverty may explain the high rate of spontaneous abortions in Monte Maiz.

There seems to be a clear link between exposure to pesticides, including glyphosate, and pregnancy loss, similar to the observations made by Settini in Italy [19], or the systematic reviews of evidence-based medicine of Sanborn et al. in MacMaster University, Canada, in 2007 [20] and updated in 2012 [21].

On the other hand, the National Registry of Congenital Abnormalities of Argentina (RENAC) in 2014 Report that between 281.249 newborns a total of 4.120 major structural congenital abnormalities were recorded, with a prevalence of $1.4 \%$ [9]; in Monte Maiz the prevalence (3\%) was twice that of the national prevalence (see Table 3). It is worth mentioning that our data does not include malformed children who died, which is why the difference could surely be even greater. The types of congenital anomalies do not differ significantly from those reported by the RENAC for the entire Province [9]. The national rate of anomalies is generated from monthly reports issued by the neonatology services, there may be underreporting of cases. By contrast, our data may be biased due to the fact that they are self-referenced, and while this is a limiting factor for any study of disease through surveys, it is unlikely in some less prevalent pathology where, on the contrary, the most common error is type II. Data collected differently may reflect discrepancies, thus generating an information bias. In any case, the higher frequency of children born with congenital abnormalities in populations exposed to agrochemicals is described for records from maternity hospitals [22], case control [23] [24], american ecological studies [25] [26], and canadian systematic reviews [21], among others.

In 2010 Paganelli demonstrates as glyphosate-based herbicides produce teratogenic effects on vertebrates by impairing retinoic acid signaling [27] and in recent years information on glyphosate genotoxicity in experimental models was published, information that was previously unknown, using test for chromosomal aberrations, micronuclei and comet assay the damage to DNA strands was verified [28] [29] even in human cells [30] [31]. More recently, these same studies were conducted in people environmentally and occupationally exposed to pesticides in general and glyphosate in particular, which reported rates of genetic damage well above those found in populations not exposed to pesticides used as reference or control groups [32] [33]. 
The Monograph Working Group of IARC-WHO in Evaluation of Carcinogenic Risks to Humans in 2015 reviews 1000 studies on glyphosate and chooses 200 relevant paper to conclude that there is strong evidence that exposure to glyphosate or glyphosate-based formulations is genotoxic based on studies in humans in vitro and studies in experimental animals [34], the occurrence of damage to the DNA strands that when not repaired nor the cell removed can lead to germ cell mutations with impact on reproductive health. Near Monte Maíz, in Marcos Juarez City, published studies showed twice frequency of chromosomal aberrations and micronuclei in environmentally exposed people to glyphosate or other pesticides [35] and genotoxicity in children exposed to pesticides comparing to not expose [36].

This association is consistent with respect to abortions and malformations, the biological plausibility is very rational for reproductive problems in their causal link with $600,000 \mathrm{~kg}$ of glyphosate polluting the environment of Monte Maiz, although recognize that the ecological fallacy cannot be discarded from this analysis and the design of this study is limited for causality. The change in time sequence could not be stated in this cross-sectional study, but local doctors noted changes in the disease profile since the introduction of GM seeds and the massive use of glyphosate. Although the methodological limitations of this exploration suggest that we acknowledge its limited scope, it highlights the association at an evidence level and should be considered with caution given the small size of the population, the self-referenced nature of the survey and the descriptive modality of the study. The results of this study are also important because they describe a health problem in the environment where the people are living.

\section{Conclusion}

This research detected an urban environment severely polluted by glyphosate and other pesticides with high environmental exposure to glyphosate in the villagers and identified elevated frequencies of congenital abnormalities and spontaneous abortion, suggesting a link between environmental exposure to glyphosate and reproductive problems, although this was an exploratory and observational design unable to make direct causal assertions. However, from the point of view of collective health, this link requires recommending the precautionary application of measures to protect the population from this environmental exposure.

\section{Acknowledgements}

To SUMA 400 Program, Secretary of University Extension from UNC that made it possible to travel with a team of 70 people to Monte Maíz. To the Municipality of Monte Maíz, that facilitated the stay of our team during the 5-day field work. To the professors and students of Medicine and Geography from UN, to the professors and students of Chemistry from the Faculty of Naturals and Exact Sciences of National University of La Plata, that conducted the chemical field 
work at Monte Maiz. And to "Ayni Translations" who carried out the translation of the Spanish original to English.

\section{Conflict of Interests}

The authors declare they have no actual or potential competing financial interests.

\section{References}

[1] Lopez, G. (2010) La Agricultura Argentina al 2020. Fundación producir conservando 2010. https://www.ucema.edu.ar/conferencias/download/2010/20.08.pdf

[2] Avila-Vazquez, M. and Difilippo, F.S. (2016) Agricultura Tóxica y Pueblos Fumigados de Argentina. Crítica y Resistencias. Revista de conflictos sociales latinoamericanos, No. 2, 23-45. http://criticayresistencias.comunis.com.ar

[3] Avila-Vazquez, M. and Nota, C. (2010) Report from the $1^{\text {st }}$ NATIONAL MEETING OF PHYSICIANS IN THE CROP-SPRAYED TOWNS. Faculty of Medical Sciences, National University of Cordoba. http://www.reduas.com.ar/wp-content/uploads/downloads/2011/10/INGLES-Repor t-from-the-1st-National-Meeting-Of-Physicians-In-The-Crop-Sprayed-Towns.pdf

[4] Di Renzo, G.C., Conry, J.A., Blake, J., DeFrancesco, M.S., DeNicola, N., Martin Jr, J.N., et al. (2015) International Federation of Gynecology and Obstetrics Opinion on Reproductive Health Impacts of Exposure to Toxic Environmental Chemicals. International Journal of Gynecology \& Obstetrics, 131, 219-225.

https://doi.org/10.1016/j.ijgo.2015.09.002

[5] Avila-Vazquez, M., Maturano, E., Etchegoyen, A., Difilippo, F.S. and Maclean, B. (2017) Association between Cancer and Environmental Exposure to Glyphosate. International Journal of Clinical Medicine, 8, 73-85. https://doi.org/10.4236/ijcm.2017.82007

[6] Scribner, E.A., Battaglin, W.A., Gilliom, R.J. and Meyer, M.T. (2007) Concentrations of Glyphosate, Its Degradation Product, Aminomethylphosphonic Acid, and Glufosinate in Ground- and Surface-Water, Rainfall, And Soil Samples Collected in the United States, 2001-06: US Geological Survey. Scientific Investigations Report 2007-5122, 14-17. http://pubs.usgs.gov/sir/2007/5122/pdf/SIR2007-5122.pdf

[7] American Public Health Association (APHA) (2012) American Water Works Association (AWWA) \& Water Environment Federation (WEF). Standard Methods for the Examination of Water \& Wastewater, 22nd Edition.

[8] Municipalidad de Monte Maíz (2015) Información General. http://www.montemaiz.gob.ar/index.php?pageid=68

[9] RENAC-REPORTE ANUAL (2014) Análisis epidemiológico sobre anomalías congénitas en recién nacidos, registradas en 2013. Ministerio de Salud. http://www.msal.gov.ar/congenitas/renac-reporte-anual-2014/

[10] Ley 9694 (2009) Provincia de Córdoba. Sistema de Evaluación, Registro y Fiscalización de las Investigaciones en Salud. https://www.unrc.edu.ar/unrc/coedi/docs/salud/sal_coeis_ley9694.pdf

[11] Castillo Taucher, S. (2007) Servicios para la atención y la prevención de defectos congénitos: Síntesis de una reunión de la Organización Mundial de la Salud y la Fundación March of Dimes. Revista Médica de Chile, 135, 806-813.

http://www.scielo.cl/scielo.php?script=sci_arttext\&pid=S0034-98872007000600018 https://doi.org/10.4067/S0034-98872007000600018 
[12] Aizen, M.A., Garibaldi, L.A. and Dondo, M. (2009) Expansión de la soja y diversidad de la agricultura argentina. Austral Ecology, 19, 45-54.

[13] REDUAS (2013) The Use of Toxic Agrochemicals in Argentina Is Continuously Increasing; Analysis of Data from the Pesticide Market in Argentina.

http://www.reduas.com.ar/the-use-of-toxic-agrochemicals-in-argentina-is-continuo usly-increasing/

[14] Open Signal (2014) Towers Identifier and Cell Coverage Map. http://opensignal.com

[15] Centro de Estudios de Estado y Sociedad (CEDES) y Centro de Estudios de Población (CENEP) (2007) Morbilidad materna severa en la Argentina, Estimación de la magnitud del aborto inducido.

http://www.despenalizacion.org.ar/pdf/evidencia/estudios/estimacion_aborto_indu cido.pdf

[16] Avila-Vazquez, M., Maturano, E., Etchegoyen, A., Difilippo, F.S. and Maclean, B. (2016) Informe Estudio de Salud Ambiental de Barrio San Antonio y Residencial San Antonio, 2016. Red Universitaria de Ambiente y Salud.

http://reduas.com.ar/informe-estudio-de-salud-ambiental-de-barrio-san-antonio-yresidencial-san-antonio-2016/

[17] Aiassa, D. (2010) Exposición a Plaguicidas. Monitoreo de daño genético en poblaciones humanas. 1 st National Meeting of Physicians in the Crop-Sprayed Towns, Cordoba, 10 August 2010, 18-20.

http://www.reduas.com.ar/wp-content/uploads/2011/04/primer-informe.pdf

[18] Arbuckle, T.E., Lin, Z. and Mery, L.S. (2001) An Exploratory Analysis of the Effect of Pesticide Exposure on the Risk of Spontaneous Abortion in an Ontario Farm Population. Environmental Health Perspectives, 109, 851-857. https://doi.org/10.1289/ehp.01109851

[19] Settimi, L., Spinelli, A., Lauria, L., Miceli, G., Pupp, N., Angotzi, G., et al. (2008) Spontaneous Abortion and Maternal Work in Greenhouses. American Journal of Industrial Medicine, 51, 290-295. https://doi.org/10.1002/ajim.20556

[20] Sanborn, M., Kerr, K.J., Sanin, L.H., Cole, D.C., Bassil, K.L. and Vakil, C. (2007) Non-Cancer Health Effects of Pesticides: Systematic Review and Implications for Family Doctors. Canadian Family Physician, 53, 1712-1720.

[21] Sanborn, M., Bassil, K., Vakil, C. and Kerr, K. (2012) Systematic Review of Pesticide Health Effects. Department of Family Medicine, McMaster University, Ontario College of Family Physicians, Toronto.

http://ocfp.on.ca/docs/pesticides-paper/2012-systematic-review-of-pesticide.pdf

[22] Trombotto, G.L. (2009) Tendencia de las Malformaciones Congénitas Mayores en el Hospital Universitario de Maternidad y Neonatología de la Ciudad de Córdoba en los años 1972-2003. Un Problema Emergente en Salud Pública (tesis). Universidad Nacional, Córdoba.

[23] Benitez Leite, S., Macchi, M.L. and Acosta, M. (2007) Malformaciones congénitas asociadas a agrotóxicos. Pediatría (Asunción), 34, 111-121.

[24] Silva, S.R., Martins, J.L., Seixas, S., Silva, D.C., Lemos, S.P. and Lemos, P.V. (2011) Congenital Defects and Exposure to Pesticides in São Francisco Valley. Revista Brasileira De Ginecologia E Obstetricia, 33, 20-26.

[25] Winchester, P.D., Huskins, J. and Ying, J. (2009) Agrichemicals in Surface Water and Birth Defects in the United States. Acta Paediatrica, 98, 664-669. https://doi.org/10.1111/j.1651-2227.2008.01207.x

[26] Schreinemachers, D.M. (2003) Birth Malformations and Other Adverse Perinatal 
Outcomes in Four U.S. Wheat-Producing States. Environmental Health Perspectives, 111, 1259-1264. https://doi.org/10.1289/ehp.5830

[27] Paganelli, A., Gnazzo, V., Acosta, H., López, S.L. and Carrasco, A.E. (2010) Glyphosate-Based Herbicides Produce Teratogenic Effects on Vertebrates by Impairing Retinoic Acid Signaling. Chemical Research in Toxicology, 23, 1586-1595. https://doi.org/10.1021/tx1001749

[28] Dallegrave, E., Mantese, F.D., Coelho, R.S., Pereira, J.D., Dalsenter, P.R. and Langeloh, A. (2003) The Teratogenic Potential of the Herbicide Glyphosate-Roundup in Wistar Rats. Toxicology Letters, 142, 45-52. https://doi.org/10.1016/S0378-4274(02)00483-6

[29] Cava, T. and Könen, S. (2007) Detection of Cytogenetic and DNA Damage in Peripheral Erythrocytes of Goldfish (Carassius auratus) Exposed to a Glyphosate Formulation using the Micronucleus Test and the Comet Assay. Mutagenesis, 22, 263-268. https://doi.org/10.1093/mutage/gem012

[30] Mañas, F., Peralta, L., Raviolo, J., García Ovando, H. and Garcia-Schuler, H. (2009) Genotoxicity and Oxidative Stress of Glyphosate: In Vivo and in Vitro Testing. Environmental Toxicology and Pharmacology, 28, 37-41.

[31] Alvarez-Moya, C., Silva, M.R., Ramírez, C.V., Gallardo, D.G., Sánchez, R.L., Aguirre, A.C. and Velasco, A.F. (2014) Comparison of the in Vivo and in Vitro Genotoxicity of Glyphosate Isopropylamine Salt in Three Different Organisms. Genetics and Molecular Biology, 37, 105-110. https://doi.org/10.1590/S1415-47572014000100016

[32] Simoniello, M.F., Kleinsorge, E.C. and Carballo, M.A. (2010) Evaluación bioquímica de trabajadores rurales expuestos a pesticidas. Medicina (B. Aires), 70, 489-498.

[33] Paz-y-Miño, C., Sánchez, M.E., Arévalo, M., Muñoz, M.J., Witte, T., De-la-Carrera, G.O. and Leone, P.E. (2007) Evaluation of DNA Damage in an Ecuadorian Population Exposed to Glyphosate. Genetics and Molecular Biology, 30, 456-460. https://doi.org/10.1590/S1415-47572007000300026

[34] Guyton, K.Z., Loomis, D., Grosse, Y., El-Ghissassi, F., Benbrahim-Tallaa, L., Guha, N., et al. (2015) Carcinogenicity of Tetrachlorvinphos, Parathion, Malathion, Diazinon, and Glyphosate. The Lancet Oncology, 16, 490-491. http://monographs.iarc.fr/ENG/Monographs/vol112/mono112-09.pdf https://doi.org/10.1016/S1470-2045(15)70134-8

[35] Peralta, L., Mañas, F., Gentile, N., Bosch, B., Mnedez, A. and Aiassa, D. (2011) Evaluación del daño genético en pobladores de Marcos Juárez expuestos a plaguicidas: Estudio de un caso en Córdoba, Argentina. DiáLogos, 2, 7-26. http://gemalab.com.ar/wp-content/uploads/2016/11/2011-Marcos-Juarez.pdf

[36] Bernardi, N., Gentile, N., Mañas, F., Méndez, A., Gorla, N. and Aiassa, D. (2015) Assessment of the Level of Damage to the Genetic Material of Children Exposed to Pesticides in the Province of Córdoba. Archivos Argentinos De Pediatria, 113, 126-132. 